\title{
Pengembangan Wisata Alam Denda Seruni Melalui Pemanfaatan Dana Desa dalam Perspektif Sosiologis
}

\author{
Azizah', Ika Wijayanti, Azhari Evendi \\ Universitas Mataram
}

\begin{abstract}
This research was studied on the development of the Denda Seruni Nature Tourism by use of village funds as well as the obstacles and efforts wich faced by the village government in developing its. This study used qualitative method with a case study approach. The informants was determined by purposive sampling and data collection techniques include observation, interviews and documentation. This research used the theory of social practice's Pierre Bourdieu which explained about (Habitus $x$ Capital + Domain) = Practice. There were four capitals in Pierre Bourdie's theory of social practice, namely, economic capital, social capital, cultural or cultural capital and symbolic capital.Through habitus owned by agents supported by economic capital through the use of village funds, social capital, cultural capital and symbolic capital created a social practice in the development of the Denda Seruni Nature Tourism. However, in the development of Nature Tourism, Denda Seruni had not been able to utilize the assets owned optimally. The lack of socialization delivered by the Village Government and Pokdarwis to the community regarding changes in tourism villages had resulted in a lack of participation and low public awareness of the importance of tourism development in the village. Therefore, the use of the habitus and capital of the Seruni Mumbul community was still not optimal and had not been effective in developing Denda Seruni tourism. The obstacles faced by the village government in developing the Denda Seruni Nature Tourism include: (1) constrained funds (2) low work ethic (3) miscommunication between managers and youth (4) misunderstanding of financial management (5) lack of socialization by Pokdarwis (6) The existence of the Covid 19 pandemic had become an obstacle in developing Denda Seruni tourism.
\end{abstract}

Keywords: Village Fund, Tourism Development, Social Practices

\begin{abstract}
Abstrak
Artikel ini membahas tentang pengembangan Wisata Alam Denda Seruni melalui pemanfaatan dana desa dan kendala serta upaya yang dihadapi oleh pemerintah desa dalam mengembangakan Wisata Alam Denda Seruni. Penelitian ini menggunakan metode kualitatif dengan pendekatan studi kasus. Penentuan informan dalam penelitian ini menggunakan purposive sampling. Teknik pengumpulan data meliputi observasi, wawancara dan dokumentasi. Adapun teori yang digunakan yaitu teori Praktik Sosial Pierre Bourdieu yang menjelaskan tentang $($ Habitus x Modal + Ranah $)=$ Praktik. Terdapat empat modal dalam teori prakik sosial Pierre Bourdie antara lain, modal ekonomi, modal sosial, modal kultural atau budaya dan modal simbolik. Melalui habitus yang dimiliki oleh agen yang didukung oleh modal ekonomi melalui pemanfaatan dana desa, modal sosial, modal budaya dan modal simbolik menciptakan sebuah praktik sosial dalam pengembangan Wisata Alam Denda Seruni. Namun, dalam pengembangan Wisata Alam Denda Seruni belum bisa
\end{abstract}

${ }^{1}$ zizah9995@gmail.com 
memanfaatkan modal-modal yang dimiliki secara optimal. Kurangnya sosialisasi dan pemberian informasi oleh pemerintah desa, pengelola dan pokdarwis mengenai perubahan status Desa Wisata kepada masyarakat Desa Seruni Mumbul menyebabkan masyarakat kurang barpartisipasi dan belum sadar sepenuhnya mengenai pentingnya pengembangan wisata di desa. Oleh karena itu pemanfaatan habitus dan modal-modal masyarakat Seruni Mumbul masih kurang maksimal dan belum efektif dalam pengembangan wisata Denda seruni. Kendala yang dihadapi oleh pemerintah desa dalam mengembangkan Wisata Alam denda Seruni antara lain: (1) Terkendala dana (2) Etos kerja masih rendah (3) Adanya mis komunikasi antara pengelola dan pemuda (4) Adanya kesalahpahaman manajemen tata kelola keuangan (5) Kurangnya sosialisasi oleh Pokdarwis (6) Adanya pandemi Covid 19 menjadi kendala dalam mengembangkan wisata Denda Seruni.

Kata Kunci: Dana Desa, Pengembangan Wisata, Praktik Sosial

\section{Pendahuluan}

Pengembangan industri pariwisata di Indonesia saat ini menjadi salah satu sektor pembangunan nasional andalan pemerintah. Hal ini disebabkan pengembangan pariwisata memiliki peranan yang penting dalam pembangunan Indonesia khususnya sebagai penghasil devisa negara disamping sektor migas. Pengembangan industri pariwisata di Indonesia telah menjadi prioritas utama dalam mendongkrak prekonomian negara. Salah satu bentuk bahwa pariwisata kini telah dijadikan sebagai prioritas pembangunan ialah dengan dikembangkannya program pembangunan 10 prioritas destinasi wisata baru yang nantinya ditargetkan devisa negara dapat mencapai US\$ 20 miliar pada tahun 2019. (Sumber: https://m.liputan6.com diakses 18 November 2019).

Salah satu daerah yang memiliki banyak potensi destinasi objek wisata yang banyak dikunjungi oleh wisatawan ialah Provinsi Nusa Tenggara Barat (NTB) tepatnya di Pulau Lombok. Saat ini pemerintah provinsi Nusa Tenggara Barat melaui Dinas Pariwisata sedang gencar-gencarnya merencanakan pengembangan desa wisata untuk memajukan sektor pariwisata di NTB. Gencarnya pengembangan desa-desa wisata yang dilakukan oleh pemerintah NTB, khususnya di Pulau Lombok tidak terlepas dari tujuan untuk meningkatkan pendapatan daerah dan mampu menciptakan lapangan pekerjaan bagi masyarakat yang ada di desa.

Dalam mengembangkan potensi yang ada di desa tentunya membutuhkan biaya sebagai faktor pendukung dalam mengembangkan wisata di desa. Oleh karena 
Pengembangan Wisata Alam Denda Seruni Melalui Pemanfaatan Dana Desa dalam Perspektif Sosiologis

itu, perlu adanya langkah strategis dalam mengembangkan potensi wisata yang ada di desa. Salah satu alternatif yang bisa dilakukan oleh desa ialah dengan memanfaatkan dana desa untuk mengembangkan potensi yang ada di desa.

Salah satu desa di Pulau Lombok yang mengembakan potensi desa sebagai objek destinasi wisata alam melaui pemanfaatan dana desa ialah Desa Seruni Mumbul. Anggaran dana desa yang diterima oleh Desa Seruni Mumbul pada tahun 2019 sebesar Rp. 1.543.182.000,00. Desa Seruni Mumbul terdiri dari tiga dusun yakni Dusun Mandar, Dusun Dames, dan Dusun Sasak. Jumlah penduduk yang tinggal di Desa Seruni Mumbul sebanyak 5.484 jiwa. 80 persen penduduknya bermata pencaharian sebagai nelayan, dimana mayoritas persebaran nelayan di desa ini terdapat di dua dusun yaitu Dusun Sasak dan Dusun Mandar. (Sumber: Profil Desa Seruni Mumbul Tahun 2019). Selain bertumpu pada sektor laut, Desa Seruni mumbul memiliki potensi-potensi yang eksotis seperti pantai, mata air, danau yang jika dikembangkan dengan baik akan meningkatkan taraf kehidupan masyarakatnya.

Salah satu potensi desa yang dikembangkan oleh Desa Seruni Mumbul menjadi destinasi objek wisata ialah sebuah danau atau biasa disebut oleh masyarakat dengan sebutan menanga atau disebut juga mumbul (mata air). Dalam menanga ini terdapat 30 mata air yang konon menurut legenda masyarakat sebagai tempat pemandian sang putri cantik jelita yang bernama Denda Seruni. Kondisi awal sebelum dibangunnya menjadi wisata, danau ini tidak terawat, banyak tumbuhan liar yang memenuhi area danau, sehingga danau ini jarang dikunjungi oleh masyarakat.

Ide awal pembangunan Wisata Alam Denda Seruni ini setelah Kepala Desa Seruni Mumbul pulang dari studi banding di Desa Ponggok Klaten Jawa Tengah. Berawal dari sana Kepala Desa Seruni Mumbul mendapatkan inspirasi untuk membangun wisata di danau yang tak terawat ini. Wisata Alam Denda Seruni ini mulai dibangun pada Januari 2019 dan diresmikan pada 5 Juni 2019 dengan memanfaatkan sebagian dari dana desa yaitu sebesar Rp. 649 juta sebagai modal dalam pembangunan wisata. Tujuan dibangunnya Wisata Alam Denda seruni ialah untuk memberdayakan masyarakat, menciptakan lapangan pekerjaan dan untuk meningkatkan perekonomian masyarakat yang ada di Desa Seruni Mumbul. 
Berdasarkan observasi awal adapun beberapa permasalahan yang ditemukan antara lain, dalam mengembangkan wisata tentunya dibutuhkan modal sosial sebagai sumber kekuatan dalam menghadapi persaingan dengan desa-desa lainnya yang juga mengembangkan wisata. Namun dalam pengembangan Wisata Alam Denda Seruni, pemerintah desa selaku pengelola masih kurang melibatkan warga dari setiap dusun dalam mengelola wisata. Hal ini tentunya menjadi permasalahan dimana, partisipasi setiap dusun sangat diperlukan untuk membangun kerjasama yang baik dalam mengembangkan wisata, terlebih lagi dalam pengembangannya menggunakan dana desa. Permasalahan lainnya yaitu, masih kurangnya skill masyarakat dalam mengelola wisata, tentunya berpengaruh pada strategi promosi yang masih kurang maksimal, serta kurang aktifnya Kelompok Sadar Wisata (Pokdarwis) Seruni Mumbul dalam mensosialisasikan mengembangkan wisata.

Oleh karena itu, berdasarkan permasalahan di atas maka penulis tertarik mengkaji (1) Bagaimana Pengembangan Wisata Alam Denda seruni yang Dilakukan Melaui Pemanfaatan Dana Desa? (2) Apa Saja Kendala dan Upaya yang Dilakukan oleh Pemerintah Desa dalam Mengembangkan Wisata Alam Denda Seruni?

Adapun penelitian terdahulu yang mengkaji permasalahan yang hampir serupa yatu Strategi Pengembangan Obyek Wisata Taman Tebing Breksi Sebagai Daya Tarik Wisata di Desa Sembijero Kecamatan Prambanan Kabupaten Sleman Yogyakarta tahun 2017 oleh Agus Tri Stiyono. Penelitian yang dilakukan Agus Tri Stiyono di Desa Sembirejo Kecamatan Prambanan Kabupaten Sleman Yogyakarta dengan fokus kajian strategi pengembangan obyek wisata taman tebing breksi sebagai daya tarik wisata. Metode penelitian yang digunakan ialah metode kualitatif deskriptif.

Hasil penelitian menujukkan bahwa pengembangan objek wisata Tebing Breksi Desa Sambijero menggunakan beberapa strategi yang baik. Adapun pihakpihak uang ikut berpartisipasi diantaranya Pemerintah Desa, masyarakat sekitar dan Dinas Pariwisata. Wujud partisipasi dari Pemerintah Desa yaitu ikut berjaga dilokasi wisata ketika hari-hari libur pada hari sabtu dan minggu, untuk masyarakat 
Pengembangan Wisata Alam Denda Seruni Melalui Pemanfaatan Dana Desa dalam Perspektif Sosiologis

sendiri ikut serta dalam kegiatan gotong royong dan juga ikut mengembangkan seni budaya khas Desa Sambirejo, dan untuk Dinas Pariwisata berpartisipasi dalam melakukan penataan ruang di obyek wisata. Dalam pengembangannya terdapat beberapa dampak positif maupun negative diantaranya membuka lapangan pekerjaan baru, semakin tingginya rasa toleransi antar sesama, adanya beberapa penyimpangan sosial yang terjadi, lebih mengenal tentang kebudayaan orang lain, perubahan sebagian masyarat yang dulunya sederhana menjadi lebih konsumtif.

Perbedaan penelitian sebelumnya dengan penelitian ini terletak pada fokus peneliti yang ingin mengetahui pengembangan wisata melalui pemanfaatan dana desa dan kendala yang dihadapi dalam mengembangakan wisata dengan metodologi penelitian kualitatif pendekatan studi kasus. Sedangkan pada penelitian di atas ingin melihat strategi pengembangan obyek wisata Tebing Breksi. Persamaan penelitian ini dengan penelitian sebelumnya yaitu sama-sama mengkaji tentang pengembangan wisata.

\section{Metode Penelitian}

Penelitian ini menggunakan metode kualitatif dengan pendekatan studi kasus. Lokasi penelitian di Desa Seruni Mumbul, Kecamatan Pringgabaya, Kabupaten Lombok Timur. Lokasi tersebut dipilih oleh peneliti karena desa Seruni Mumbul salah satu desa yang mengembangkan wisata menggunakan dana desa. Subyek dalam penelitian ini adalah individu, terdiri dari informan kunci dan informan pendukung.

Teknik pengumpulan data menggunakan observasi, wawancara mendalam dan dokumentasi. Berdasarkan observasi awal pada 6 Oktober 2019, terdapat beberapa permasalahan yang ditemukan yaitu: (1) pemerintah desa selaku pengelola masih kurang melibatkan warga dari setiap dusun dalam mengelola wisata. Hal ini tentunya menjadi permasalahan dimana, partisipasi setiap dusun sangat diperlukan untuk membangun kerjasama yang baik dalam mengembangkan wisata, terlebih lagi dalam pengembangannya menggunakan dana desa. (2) masih kurangnya skill masyarakat dalam mengelola wisata, tentunya berpengaruh pada strategi promosi 
yang masih kurang maksimal, (3) kurang aktifnya Kelompok Sadar Wisata (Pokdarwis) Seruni Mumbul dalam mensosialisasikan mengembangkan wisata.

Pengumpulan data melalui wawancara dilakukan dari tanggal 10 Februari sampai 20 Juni. Informan wawancara dalam penelitian ini antara lain: Orang-orang yang menjabat dalam Pemerintahan Desa yang yaitu: Kepala Desa, Sekertaris Desa, Bendahara Desa dan Ketua Bumdes, Orang-orang yang berpengaruh di masyarakat yaitu: Kadus/RT, Tokoh agama, Tokoh masyarakat yang berperan dalam Tim Pelaksana Kegiatan (TPK) dan Tokoh pemda. Orang-orang yang terlibat dalam mengelola wisata yaitu: pengelola wisata Denda Seruni, Kelompok Sadar Wisata (Pokdarwis), pedagang, dan masyarakat. Dalam penelitian ini dokumentasi berupa foto-foto wawancara, rekaman wawancara dan catatan lapangan.

\section{Hasil dan Pembahasan}

\section{Habitus Masyarakat Seruni Mumbul Dalam Pengembangan Wisata Alam Denda Seruni}

Habitus merupakan struktur mental (kognitif) yang digunakan aktor (indivdu atau kelompok) untuk menghadapi kehidupan sosial. Dalam hal ini aktor dibekali seperangkat nilai, norma dan pengetahuan di lingkungan manapun ia berada, seperangkat sistem tersebutlah yang nantinya berguna untuk menghadapi dunia. Dengan demikian, habitus bersifat "diciptakan dan menciptakan" atau dengan kata lain "struktur yang menstrukturkan" (Ritzer, 2006).

Proses habitus yang dilalui dalam pembuatan Desa Wisata Seruni Mumbul berawal dari potensi yang dimiliki berupa mata air Mumbul. Potensi tersebut membuat banyak wisatawan datang berkunjung. Namun, disatu sisi lokasi tersebut dijadikan sebagai tempat membuang sampah oleh masyarakat dan sebagai tempat untuk melakukan perilaku menyimpang dengan meminum-minuman keras, dimana tindakan tersebut tidak sesuai dengan nilai dan norma yang berlaku di Desa tersebut. Melihat potensi dan permasalahan yang terjadi maka pihak Perangkat Desa mencoba mencari solusi agar potensi dan permasalahan di Desa Seruni Mumbul bisa di atasi. Adapun salah satu usaha yang dilakukan adalah dengan mengikuti studi banding terkait pengembangan desa wisata ke Desa Umbul Ponggok Klaten 
Pengembangan Wisata Alam Denda Seruni Melalui Pemanfaatan Dana Desa dalam Perspektif Sosiologis

yang diwakili oleh Kepala Desa Seruni Mumbul. Hal tersebut sebagaimana diungkapkan oleh informan BN yang mengatakan bahwa :

"Pada walnya kami ber empat pada waktu itu berfikr untuk membangun wisata, tapi belum tau nih mau bangun apa, bahkan mumbul ini belum masuk dibayangan kami. Jadi kami berempat bersama pak kepala berfikir membangun sesuatu untuk mengurangi kemiskinan untuk mengangkat ekonomi. Kami berfikir masa dengan dana sebanyak ini kita ndak bisa bangun apa-apa. Pak kepala berfikir tolak ukur kesejahteraan itu adalah bagaimana perut orang itu terisi bukan seberapa bagus jalan yang dilalui, seberapa besar pembangunan di desa itu, jadi bagaimana nih masyarakat ini ada kerjaan lah. Jadi waktu itu kan masih tahun 2018 masih ide aja, nah kemudian pergilah pak Kepala Desa ke Klaten untuk studi banding, nah pas pulang dia banyak dapet ilmu dia tau apa yang harus kita bangun supaya bagus wisata ini bagaimana modelnya"

Melalui studi banding yang dilakukan oleh aktor yaitu kepala desa, maka diperoleh pengetahuan terkait pengembangan Desa Wisata. Dari hasil pengetahuan tersebut kepala Desa Seruni Mumbul melakukan upaya dengan mensosialisasikan pengetahuan yang diperoleh kepada masyarakat melalui kegiatan musdus, musdes dan musrembangdes. Hal tersebut sebagaimana diungkapkan oleh informan TJ yang mengatakan bahwa:

"Jadi dalam pembangunan desa itu kan ada namnya Musdus. Pertama kita adakan musyawarah dusun dulu di setiap dusun kita undang semua masyarakat dan tokoh-tokoh masyarakat disana, bersama tim pelaksana musdus kita sampaikan permasalahan desa dan ide-ide pembangunan desa termasuk pembangunan wisata ini juga kita sampaikan kepada mereka yang hadir.

Hasil dari interaksi yang berlangsung melalui kegiatan tersebut melahirkan pengetahuan yang disepakati secara bersama oleh semua elemen masyarakat dan pemerintah setempat untuk pembangunan mata air mumbul menjadi wisata alam Denda Seruni melalui pemanfaatan dana desa. Keputusan yang diambil oleh aktor dalam membangun Desa wisata dengan memanfaatkan dana desa didasari karena adanya pengetahuan aktor bahwa dana desa harus dimanfaatkan dengan sebaik mungkin untuk mengurangi kemiskinan. Hal ini karena, di desa ini banyak masyarakat khusunya pemuda yang menjadi pengangguran karena rendahnya pendidikan yang disebabkan letak geografis yang berada di pesisir pantai. Kondisi 
geografis terebut membuat banyak orang tua beranggapan bahwa lebih baik anakanaknya melakukan aktivitas sebagai seorang nelayan dibanding untuk menempuh pendidikan. Hal tersebut sebagaiaman diungkapkan oleh informan LH mengungkapkan bahwa:

"Di desa kan pekerjaan disini nelayan karena dekat dengan pesisir banyak anak-anak ini atau pemuda-pemuda ini yang tidak melanjutkan sekolahnya lebih baik mereka di suruh pergi memancing sama orang tuanya cepet dapet uang kadang juga keinginan anak itu yang ndak mau sekolah lebih baik ikut mancing nyata hasilnya diliat cepet dapet uang"

Rendahnya minat anak dalam menempuh pendidikan menjadi sebuah nilainilai dalam masyarakat dan menjadi sebuah habitus, dimana mereka bertindak sesuai dengan nilai-nilai yang ada di tempat tinggal mereka. Berangkat dari permasalahan tersebut aktor yang dalam hal ini pemerintah desa memilih untuk mengembangkan wisata di desa supaya bisa menyerap tenaga kerja khusunya para pemuda yang belum memiliki pekerjaan. Proses yang berlangsung tersebut menurut Bourdieu merupakan tahap habitus yang dilalui oleh aktor dalam hal ini kepala Desa yang dibekali dengan adanya potensi, nilai norma dan pengetahuan di Desa Seruni Mumbul sehingga terbentuklah Wisata Alam Denda Seruni.

Tidak hanya itu, habitus pada Mayarakat Di Desa Seruni Mumbul tercermin dari mayoritas masyarakatnya yang bekerja sebagai seorang nelayan. Dimana, dalam kehidupan bermasyarakat semangat melaut yang diwariskan oleh orang tua dalam menghidupi keluarga membakar semangat dalam diri mereka menjadi nilai yang positif yang tertanam dalam diri mereka dalam menjalakan pekerjaan sebagai nelayan. Setiap sore warga yang bekerja sebagai nelayan pergi berkelompok menggunakan perahu untuk memancing ikan. Ketika perahu warga pulang memancing pada waktu subuh, para ibu-ibu yang bekerja sebagai pedagang ikan bersama-sama menunggu hasil tangkapan suami atau para nelayan di bibir pantai.

Kebiasaan yang dilakukan oleh masyarakat tersebut merupakan sikap mental atau tindakan yang dilakukakn secara tidak langsung berkontribusi dari hasil interaksi antar sesama warga menciptakan nilai-nilai kebersamaan dalam kehidupan. Habitus dibentuk melalui proses yang panjang, sebagaimana semangat 
Pengembangan Wisata Alam Denda Seruni Melalui Pemanfaatan Dana Desa dalam Perspektif Sosiologis

masyarakat Seruni serta nilai-nilai yang tertanam dalam diri mereka membutuhkan waktu yang lama.

Masyarakat yang tinggal di Desa Seruni Mumbul terdiri dari beberapa etnis yaitu, Sasak, Mandar, Bugis, Jawa dan Samawa. Rasa saling menghormati dan menghargai menjadi salah satu nilai yang dipegang oleh masyarakat untuk menciptakan kehidupan yang rukun. Hal ini dikarenakan mayoritas etnis Sasak yang tinggal di wilayah Desa Seruni Mumbul nilai-nilai budaya khas Sasak menjadi pegangan dalam kehidupan bermasyarakat.

Salah satu bentuk saling menghargai dan menghormati yang diterapkan dalam kehidupan masyarakat Seruni Mumbul dilihat ketika sebelum mengadakan acara besar, seperti pernikahan, khitanan dan aqiqah. Warga yang menggelar acara, dua hari atau tiga hari menjelang prosesi tersebut mengundang atau dalam bahasa sasaknya Pesilaq warga dengan cara mengutus dua orang berkeliling kampung mendatangi rumah-rumah warga untuk memberitahu perihal acara tersebut.

Selain nilai saling menghormati dan menghargai yang diterapkan dalam masyarakat Seruni nilai kebersamaan atau gotong royong menjadi pegangan msayarakat, seperti pada acara Begawe atau pernikahan masyarakat saling membantu bekerja bersama-sama menyiapkan segala keperluan pernikahan, kemudian diadakannya gotong royong disetiap dusun pada hari Jum'at atau masyarakat menyebutnya dengan Jum'at bersih. Selain itu sikap kerjasama atau gotong royong terlihat ketika ada warga yang meninggal, masyarakat Seruni berbondong-bondong datang ke rumah duka atau dalam bahasa sasaknya disebut Belangar untuk mencucapkan bela sungkawa dengan membawa amplop berisi uang sebagai bentuk bantuan yang diberikan oleh warga dan membantu bersama-sama dalam proses penguburan.

Secara tidak disadari kebiasaan-kebiasaan yang dilakukan melalui proses interaksi dalam jangka waktu yang lama ini telah melekat menjadi sebuah nilainilai yang tertanam dalam diri individu atau masyarakat yang tercipta melalui praktik-praktik sosial dengan angggota masyarakat dan lingkungannya, sehingga menjadi sebuah habitus dalam kehidupan masyarakat Seruni. Habitus ini merupakan seperangkat pengetahuan untuk memahami nilai-nilai tersebut untuk diaplikasikan 
kedalam kehidupan nyata (Jenkis, 2013). Nilai menghargai menghormati dan gotong royong inilah yang dapat dimanfaatkan oleh masyarakat untuk mengembangkan segala usaha termasuk dalam mengembangkan wisata. Berikut adalah dokumentasi wisata alam Dende Seruni.

Gambar 1. Sebelum dibangun wisata

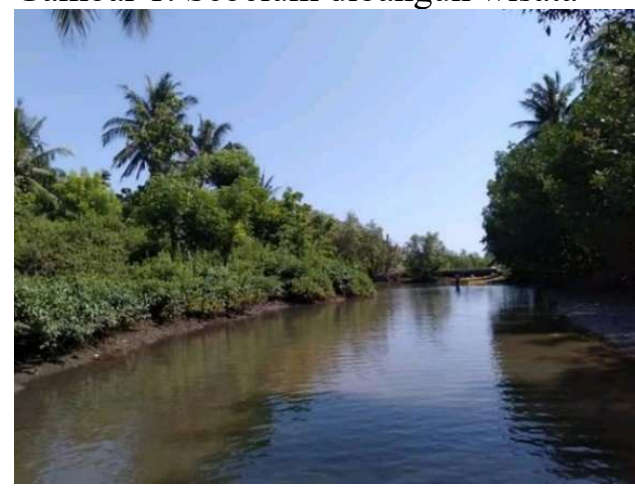

Sumber: Facebook Aunur Rofik
Gambar 2. Setelah dibangun wisata

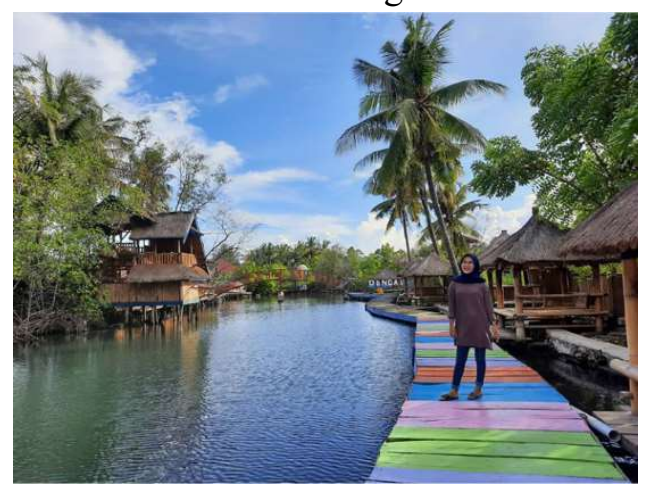

Sumber: Instagram Denda Seruni

\section{Penggunaan Modal Dalam Pengembangan Wisata Alam Denda Seruni}

1. Modal Ekonomi

Modal Ekonomi, merupuakan segala bentuk modal yang dimiliki berupa alat-alat produksi (alat produksi (mesin, tanah, tenaga kerja), materi (pendapatan, benda-benda), dan uang. (Ritzer, 2006). Modal ekonomi Masyarakat Seruni Mumbul untuk membangun Wisata Alam Denda Seruni memanfaatkan sebagian dari dana desa sebesar Rp.649 juta sebagai modal awal dalam mengembangkan wisata. Selain dana desa, modal ekonomi yang dimiliki masyarakat yaitu, perahu yang digunakan untuk memancing, potensi berupa lahan atau danau yang dijadikan objek wisata, tanah, rumah, serta kendaraan yang mereka miliki. Modal ekonomi yang dimiliki oleh Desa Seruni Mumbul ini menjadi penggerak bagi modal-modal yang lainnya dalam mengembangkan usaha yang nantinya akan mempengaruhi modal-modal yang lainnya. simboliknya. Perluasan modal ekonomi tidak terlapas dari kontribusi modal sosial dan modal kultural yang mereka miliki. Karena sejatinya modal-modal tersebut tidak berdiri sendiri melainkan saling terhubung dan saling mempengaruhi. 
Pengembangan Wisata Alam Denda Seruni Melalui Pemanfaatan Dana Desa dalam Perspektif Sosiologis

\section{Modal Sosial}

Bourdieu menyebutkan bahwa modal sosial ialah hubungan-hubungan dan jaringan hubungan-hubungan yang merupakan sumber daya yang berguna dalam penentuan dan reproduksi kedudukan-kedudukan sosial. Dalam modal sosial terdapat unsur-unsur pokok yang terdiri dari partisipasi dalam suatu jaringan, resiprositas, kepercayaan, norma sosial, nilai-nilai, tindakan yang proaktif.

Modal sosial dalam pengembangan wisata Denda Seruni dapat dilihat pada partisipasi masyarakat ketika proses perencanaan pembangunan wisata. Dalam proses perencanan pembangunan wisata Desa Seruni Mumbul dilakukan melalui tiga tahapan, yaitu Musdus (Musyawarah Dusun), Musdes ( Musyawarah Desa), dan Musrenbangdes (Musyawarah Rencana Pembangunan Desa). Dalam proses ketiga musyawarah tersebut terjalin hubungan atau interaksi-interaksi antara unsurunsur masyarakat, yaitu perangkat desa, tokoh-tokoh masyarakat, kelompok pemuda dan kelompok wanita yang menghadiri musyawarah perencanaan pembangunan Desa Seruni Mumbul. Dalam interaksi tersebut ada ketentuanketentuan yakni: (1) setiap unsur-unsur masyarakat harus menghadiri musdus, musdes, dan musrenbangdes. (2) masyarakat harus mengusulkan ide-ide , (3) dibentuk tim-tim kerja yang memiliki tugas masing-masing. Dari hasil interaksi dalam kegiatan perencanaan pembangunan tersebut diperoleh hasil kesepakatan yang berbentuk norma tertulis dan tidak tertulis.

Norma tertulis tersebut tercermin dari adanya peraturan yang dituangkan ke dalam Perdes Pengelolaan Wisata dan Penyewaan Aset Desa antara lain: (1) berpakaian rapi, (2) tidak membawa makanan dari luar areal wisata, (3) tidak membawa minuman keras atau minuman sejenisnya yang dapat memabukkan, (4) tidak berbuat tindakan asusila/mesum, (5) tidak membuat kerusakan dan menjaga kebersihan areal wisata dengan tidak membuang sampah sembarangan.

Norma yang tidak tertulis diantaranya, (1) wisata tidak boleh beroperasi malam atau lebih dari jam 6, (2) tidak membolehkan anak-anak sekolah masuk ke wisata di jam belajar terkecuali ada keperluan yang berkaitan dengan kegiatan pembelajaran. (3) pengelola dan masyarakat sekitar wisata harus menjaga kebersihan lingkungan, (4) saling mengontrol keadaan wisata untuk mencegah 
kegiatan asusila/mesum dalam wisata seperti, pengelola dan masyarakat khususnya yang berjualan di dalam lokasi wisata mengontrol keadaan dengan cara diam-diam berkeliling mengamati para pengunjung yang ingin berbuat tindakan asusila.

Proses perencanaan pembangunan desa yang dilakukan melalui musyawarah-musyawarah tersebut melahirkan suatu modal sosial dalam bentuk norma-norma, dimana dalam norma tersebut terdapat nilai-nilai agama yang dijadikan sebagai pedoman dalam pelaksanaan kegiatan pariwisata di Wisata Alam Denda Seruni.

Partisipasi Masyarakat Desa Seruni Mumbul juga terlihat dalam keikutsertaan masyarakat dalam suatu perkumpulan-perkumpulan seperti: perkumpulan pemuda Karang Taruna, kelompok arisan, perkumpulan RT, Pokdarwis, ibu-ibu PKK, Kelompok masyarakat nelayan Optimis dan kelompok keagamaan seperti perkumpulan pengajiaan. Perkumpulan-perkumpulan tersebut dapat dimanfaatkan untuk mengikat hubungan masyarakat Seruni Mumbul. Jalinan jaringan akan mudah terbentuk dari adanya hubungan interaksi masyarakat. Jika perkumpulan-perkumpulan tersebut dilaksanakan secara efektif, tidak dipungkiri dapat membangun solidaritas positif masyarakat Seruni Mumbul dalam mengembangkan wisata.

Selanjutnya modal sosial menurut Bourdieu juga terlihat dari adanya Resiprositas (hubungan timbal balik) dalam kehidupan masyarakat Seruni Mumbul yang ditunjukkan dengan adanya sikap saling menghargai, menghormati dan gotong royong dalam membantu satu sama lain ketika ada masyarakat yang membutuhkan bantuan seperti acara perikahan dan aqiqah bahkan ketika ada warga yang meninggal dunia. Hubungan timbal balik yang dilakukan antar warga dari sejak dahulu telah menjadi nilai-nilai positif yang melekat dalam kehidupan bermasyarakat yang secara tidak sadar menumbuhkan rasa saling percaya antar sesama warga dalam kehidupan sosialnya.

Tindakan resiprositas yang terjalin dalam masyarakat Seruni Mumbul dilaksanakan berdasarkan rasa saling percaya antara individu satu dengan yang lainnya. Mereka mempercayai tetangga mereka yang memberikan bantuan. Kepercayaan tersebut telah tumbuh dan berkembang dalam kehidupan sehari-hari. 
Pengembangan Wisata Alam Denda Seruni Melalui Pemanfaatan Dana Desa dalam Perspektif Sosiologis

Kepercayaan tersebut didasari dan ditumbuhkan oleh nilai dan norma yang dipegang oleh masyarakat. Nilai menghargai dan membantu sesama telah tumbuh karena terdapat rasa saling percaya antara individu satu dengan lainnya.

Kemampuan masyarakat khusunya pengelola dan Pokdarwis untuk berpartisipasi mengikuti pelatihan dapat membangun kerjasama. Melalui pelatihan dan studi banding yang dilakukan di Wisata Denda Seruni secara tidak langsung dapat memperluas jaringan sosial yang dimiliki. Melalui interaksi-interaksi yang dilakukan dalam kegiatan studi banding terjalin kerjasama-kerjasama dengan berbagai pihak seperti, Kemetrian desa, Dinas Pariwisata, BLK dan desa-desa wisata. Dalam hubungan kerjasama tersebut terdapat pola hubungan timbal balik (resiprositas) yang saling menguntungkan antar kedua belah pihak dimana wisata lebih dikenal oleh masyarakat luar sebagai bentuk strategi promosi dalam mengambangkan wisata, sedangkan bagi pihak yang bekerjasama diuntungkan mendapatkan program-program yang dapat dijalankan di wisata Denda seruni.

Dalam pengembangan Wisata Alam Denda Seruni nilai keramah tamahan masyarakat Seruni menjadi modal dalam mengembangkan wisata. Adapun tindakan proaktif dalam pengembangan Wisata Alam Denda Seruni yang dilakukan oleh masyarakat yaitu, menjaga keamanan, kebersihan, seperti mempercantik halaman rumah dengan memperbaiki pagar-pagar halaman rumah memberikan kesan warnawarni dengan mengecat pagar-pagar kayu mereka. Selain itu tindakan proaktif yang dilakukan oleh masyarakat Seruni dengan memanfaatkan adanya wisata seperti, menjual makanan dan minuman, mengelola wisata, dan menjadi tukang parkir. Tindakan-tindakan tersebut dilakukan untuk menambah penghasilan dan secara tidak langsung tindakan tersebut mendukung pengembangan wisata.

Unsur-unsur modal sosial menurut Bourdieu diatas yang ada dalam masyarakat Seruni Mumbul apabila dimanfaatkan secara maksimal dapat memberiakan kontribusi dalam mengembangkan Wisata Denda Seruni. Namun, pemanfaatan modal sosial yang sudah dimiliki oleh masyarakat Seruni dalam pengembangan Wisata Denda Seruni belum optimal dilakukan oleh masyarakat. Kurang aktifnya kelompok-kelompok masyarakat terutama Pokdarwis dalam mensosialisasikan pentingnya pengembangan wisata pedesaan menyebabkan 
masyarakat belum mengetahui perubahan status Desa Seruni Mumbul menjadi Desa Wisata, sehingga masyarakat belum sadar dan belum memahami bahwa ada peluang untuk memajukan desa. Selain itu pemanfaatan modal sosial belum maksimal dikarenakan masih kurangnya partisipasi dari dusun-dusun lain dalam mengembangkan wisata Denda Seruni.

3. Modal Kultural atau Budaya

Bourdieu memberikan pandangan bahwa modal budaya adalah keseluruhan kualifikasi inetelektual yang bisa diproduksi melalui pendidikan formal maupun warisan keluarga, seperti kemampuan menampilkan diri di depan publik, kepemilikan benda-benda budaya bernilai tinggi, pengetahuan dan keahlian tertentu hasil pendidikan formal. Modal kultural pada dasarnya berupa keyakinan nilai-nilai mengenai segala sesuatu yang dipandang benar dan senantiasa diikuti dengan upaya untuk mengaktualisasikannya.

Kebiasaan gotong royong, saling menghormati, menghargai dan membantu dalam acara-acara besar seperti pernikahan, khitanan telah diwariskan oleh orang tua-orang tua terdahulu menjadi salah satu modal budaya dalam bekerja sama mengembangkan wisata. Selain itu dipercayainya cerita sejarah legenda kisah Denda Seruni dan Datu Mumbul menjadi modal budaya dalam mengembangkan wisata edukasi untuk mengenal sejarah Desa Seruni Mumbul. Namun, adanya cerita legenda Denda Seruni belum dimanfaatkan secara optimal oleh pengelola wisata dalam menciptakan wisata yang berbasis edukasi.

\section{Modal Simbolik}

Menurut Bourdieu modal simbolik, mengacu pada derajat akumulasi prestise, ketersohoran, konsekrasi atau kehormatan, dan dibangun di atas dialektika pengetahuan (connaisence) dan pengenalan (reconnaissance). Modal simbolik dapat berupa kantor yang luas di daerah mahal, mobil dengan sopirnya, namun bisa juga pentunjuk-petunjuk yang tidak mencolok mata yang menunjukkan status tinggi pemiliknya. Misalnya, gelar pendidikan yang dicantumkan di kartu nama, cara menginformasi otoritasnya. 
Pengembangan Wisata Alam Denda Seruni Melalui Pemanfaatan Dana Desa dalam Perspektif Sosiologis

Modal simbolik yang kasat mata dimiliki oleh masyarakat Seruni Mumbul berupa rumah, kendaraan, perahu, lahan atau tanah. Sedangkan modal simbolik yang tak kasat mata yang dimilik oleh masyarakat berupa gelar dan kedudukan dalam struktur masyarakat. Tokoh-tokoh masyarakat dan perangkat desa yang memiliki gelar dan kedudukan dalam masyarakat.

Mata air atau mumbul merupakan salah satu modal simbolik yang kasat mata dimiliki oleh masyarakat Desa Seruni Mumbul, dikarenakan lokasi ini memiliki nilai sejarah dari kisah Denda Seruni dan Datu Mumbul yang dikenal oleh masyarakat luar, sehingga dijadikan sebagai tempat belangon. Dalam perencanaan pembangunan wisata terdapat peran modal simbolik dari kepala desa yang menjadi penggagas ide pembangunan wisata. Dikarenakan kepala desa memiliki status sosial yang tinggi dalam masyarakat, sehingga usulan dari kepala desa mengenai pembangunan Wisata Denda Seruni dijadikan prioritas pembangunan mudah didengarkan oleh masyarakat.

Modal simbolik yang dimiliki oleh perangkat desa dan tokoh-tokoh masyarakat dalam mengembangkan wisata Denda Seruni dapat dimanfaatkan untuk memberikan sugesti atau arahan dan instruksi kepada masyarakat dalam mengembangkan wisata. Selain itu modal simbolik yang dimiliki oleh perangkat desa ini dapat dimanfaatkan dalam menjalin kerjasama untuk mengembangkan wisata seperti membangun kerjasama dengan pemerintah Kementrian Desa dan Dinas Pariwisata akan lebih mudah diperhatikan. Namun, karena pemanfaatan modal simbolik yang dimiliki oleh perangkat desa dalam mengembangkan wisata Denda Seruni belum optimal dikarenakan masih kurangnya sosialisasi dari pemerintah desa dan adanya kontra tokoh agama yang tidak setuju sebelum pembangunan wisata Denda Seruni mempengaruhi pengembangan wisata. Pemanfatan modal simbolik ini akan berjalan baik apabila dalam pemanfaatannya dilakukan secara bijaksana agar berjalan optimal.

\section{Ranah Pengembangan Wisata Alam Denda Seruni}

Ranah merupakan tempat untuk persaingan dan perjuangan. Dalam kehidupan sosial masyarakat harus menguasai dan memahami kondisi-kondisi yang terdapat dalam lingkungan masyarakat. Bourdieu mengatakan bahwa di dalam suatu 
ranah, agen-agen menempati posisi yang tersedia untuk terlibat dalam suatu kompetisi untuk memperebutkan kontrol kepentingan atau sumber. Desa Seruni Mumbul yang sekarang statusnya telah berubah menjadi desa wisata tentunya mengharuskan masyarakatnya memiliki kesaradaran, kemampuan (skill) atau keterampilan agar mampu bertahan dalam kondisi desa wisata. Ranah yang dimaksudkan disini adalah tempat di mana masyarakat Seruni Mumbul tinggal, yaitu Desa Seruni Mumbul.

Desa Seruni Mumbul merupakan tempat anggota masyarakat berjuang dan bersaing mempertahankan kedudukan sosial. Selain bersaing dalam mendapatkan penghasilan, masyarakat Seruni juga bersaing dalam hal keahlian. Desa Seruni Mumbul yang kini telah statusnya telah berubah menyandang desa wisata dapat memanfaatkan status tersebut untuk mengasah kemampuan berketerampilan dalam melakukan inovasi-inovasi dan meningkatkan kreatifitas masyarakat sekaligus untuk bersaing dalam mengembangkan Desa wisata. Tetapi, pada kenyataannya di dalam ranah tersebut masyarakat Seruni Mumbul belum secara optimal memanfaatkan modal-modal yang mereka miliki, yang dalam hal ini ranah yang dimaksud ialah Desa Seruni Mumbul. Modal ekonomi, sosial, kultural/budaya dan modal simbolik yang dimiliki oleh masyarakat Seruni Mumbul seharusnya dapat dimanfaatkan sedemikian rupa agar dapat menciptakan desa wisata yang sesuai dengan kriteria desa wisata pada umumnya.

Kurangnya sosialisasi dan pemberian informasi oleh pemerintah desa, pengelola dan pokdarwis mengenai perubahan status Desa Wisata kepada masyarakat Desa Seruni Mumbul menyebabkan masyarakat kurang barpartisipasi dan belum sadar sepenuhnya mengenai pentingnya pengembangan wisata di desa. Oleh karena itu pemanfaatan habitus dan modal-modal masyarakat Seruni Mumbul masih kurang maksimal dan belum efektif dalam pengembangan wisata Denda seruni.

Ranah Desa Seruni Mumbul ini merupakan tempat hubungan relasional. Masyarakat bisa bekerja sama satu dengan yang lainnya untuk berusaha secara bersama-sama dalam mengembangkan Wisata Alam Denda Seruni untuk meningkatkan taraf hidup masyarakat dalam suatu desa wisata. Selain hubungan 
Pengembangan Wisata Alam Denda Seruni Melalui Pemanfaatan Dana Desa dalam Perspektif Sosiologis

satu dengan yang lainnya dalam masyarakat, membangun hubungan relasi jaringan dengan pemerintah, baik itu kabupaten, kecamatan maupun desa ke masyarakatnya. Hal ini dikarenakan pembangunan wisata Denda Seruni di Desa Wisata Seruni Mumbul tidak berdiri sendiri, tetapi merupakan satu kesatuan tujuan yang sama yaitu saling menguntungkan untuk pihak-pihak yang terkait. Dalam hal ini melalui pemerintah Desa Seruni Mumbul telah bekerjasama dengan Kementrian Desa, Dinas Pariwisata, BLK dan bekejasama dengan desa wisata lainnya. Hubungan kerjasama yang telah terjalin ini tentunya menguntungkan satu sama lain. Dalam ranah ini mereka harus berusaha dengan memanfaatkan habitus positif mereka dan modal-modal yang sudah dimiliki agar dapat menguasai dan memanfaatkan ranah pengembangan wisata tersebut dengan baik.

\section{Praktik Sosial Masyarakat Seruni Mumbul}

Menurut Bourdieu dalam dunia sosial tidak hanya berbicara masalah perilaku yang dimunculkan oleh individu dan struktur. Bourdieu berpendapat bahwa dunia sosial merupakan praktik sosial. oleh karenanya Bourdieu mengemukakan rurmus generatifnya dengan persamaan sebagai berikut: (Habitus x Modal) + Ranah $=$ Praktik. Dengan kata lain habitus yang membawa modal untuk bersaing dalam ranah praktik (Jenkis, 2013).

Dalam persamaan tentang habitus, modal, ranah dan praktik yang disampaikan oleh Bourdieu dapat digambarkan bahwa melalui habitus yang dimiliki oleh agen yang didukung oleh modal ekonomi melalui pemanfaatan dana desa, modal sosial, budaya dan simbolik menciptakan sebuah praktik sosial dalam pengembangan Wisata Alam Denda Seruni.

\section{Dampak Pengembangan Wisata Alam Denda Seruni}

Dibangunnya Wisata Alam Denda Seruni memiliki dampak positif yang dirasakan oleh masyarakat Seruni Mumbul yaitu, (1) bisa membuka lapangan pekerjaan khususnya bagi para pemuda, (2) menumbuhkan kereatifitas pemuda, (3) menambah Anggaran Pendapatan Desa Seruni Mumbul, (4) menghilangkan stigma negatif yang mengatakan mumbul tempat untuk minum-minuman keras dan hal-hal mistik.Ketika wisata sudah dibangun di Danau Mumbul sudah tidak ada lagi orangorang yang membuang sampah sembarangan ataupun membuang bangkai hewan 
yang sudah mati, (5) Desa Seruni Mumbul lebih dikenal oleh masyarakat luar serta mendapat perhatian dari pemerintah. (6) Masyarakat Seruni Mumbul khusunya Dusun Mandar menjadi titik lokasi wisatamulai sadar pentingnya menjaga lingkungan agar tetap bersih demi kenyamanan bersama dan kenyamanan pengunjung.

Sedangkan dampak negatif yang dirasakan oleh masyarakat khusunya Dusun Mandar yaitu, (1) menimbulkan kebisingan ketika kendaraan sepeda motor atau mobil keluar masuk wisata, karena jalur masuk wisata melewati pemukiman warga ditambah jalannya yang masih berkerikil-kerikil. (2) keselamatan anak-anak yang sedang bermain di jalan menjadi kehawatiran masyarakat untuk selalu mengawasi anak-anak ketika bermain.

Kendala dan Upaya yang dihadapi oleh Pemerintah Desa Dalam Mengembangakan Wisata Alam Denda Seruni

Adapun kendala dan upaya yang dihadapi pemerintah desa dalam mengembangkan Wisata Alam Denda Seruni antara lain sebagai berikut (1) terkendala dana, Dalam pengembangan wisata alam denda seruni, pemerintah desa memiliki harapan kedepannya untuk memajukan wisata dengan membuat wisata mangrove yang akan dihubungkan ke wisata denda seruni terkendala oleh dana. Adapun upaya yang sedang dilakukan dalam mengatasi kendala tersebut, yaitu dengan menggunakan anggaran pendapatan wisata sebanyak 15\% untuk perbaikan wisata. Untuk pengembangan ke wisata mangrove pemerintah desa telah mengajukan proposal permohonan dana ke Kementrian Desa. (2) Etos kerja masih rendah, dalam perekrutan pengelola wisata telah dipilih 10 anggota dari setiap dusun dari setiap dusun kecuali dusun Dames tidak ada perwakilan pemuda dikarenakan alasan jarak yang jauh dan lebih memilih merantau ke Bali. Pemerintah desa menggunakan sistem trainning untuk melihat kesungguhan pemuda untuk mrengelola wisata Selain itu pada proses trainnning dalam mengelola wisata sebanyak 4 orang mengundurkan diri dengan alasan pribadi dan ingin mencari pekerjaan lain. Hal tersebut menandakan bahwa etos kerja dari pemuda-pemuda untuk mengelola wisata masih rendah. Upaya yang dilakukan oleh pemerintah desa tidak ada. (3) Adanya mis komunikasi antara pengelola dan 
Pengembangan Wisata Alam Denda Seruni Melalui Pemanfaatan Dana Desa dalam Perspektif Sosiologis

pemuda, Adanya mis komunikasi dikalangan pemuda dalam proses perekrutan pengelola wisata menyebabkan kecemburuan dan ketidakharmonisan antara pengelola wisata dengan kelompok pemuda. Pada proses perekrutan pengelola beberapa pemuda tidak hadir mengakibatkan kurangnya informasi yang didapatkan dan menyebabkan adanya gesekan antara pemuda dan pengelola. Namun, permasalahan mengenai hal ini telah diselesaikan melalui proses pertemuan antara pengelola dan kelompok pemuda. (4) Adanya kesalahpahaman mengenai tata kelola menejemen keuangan dalam perhitungan PADes (Penghasilan Asli Desa) yang terjadi antara pengurus Bumdes dengan pemerintah desa menimbulkan kurangnya harmonisasi antar lembaga dan pemerintahan desa secara tidak langsung dapat mempengaruhi jalannya pengembangan wisata. Upaya yang dilakukan oleh pemerintah desa dalam menangani permasalahan tersebut dengan mengadakan pertemuan antara pemerintah desa dengan pihak Bumdes untuk mengklarifikasi permasalahan tersebut. (5) Kurangnya sosialisasi yang dilakukan oleh Pokdarwis mengenai Perubahan status Desa Seruni Mumbul menjadi Desa wisata belum diketahui oleh masyarakat menyebabkan masih kurangnya partisipasi masyarakat dalam mengembangkan wisata Denda Seruni.Upaya yang akan dilakukan oleh Pokdarwis rencananya akan mengadakan sosialisasi setelah pandemi Covid -19 (6) Dikarenakan adanya pandemi Covid 19, segala bentuk kegiatan perkumpulan untuk sementara waktu dihentikan termasuk kegiatan wisata menyebabkan pemasukan wisata menurun.

\section{Kesimpulan}

Berdasakan hasil temuan penelitian tentang Pengembangan Wisata Denda Seruni melalui pemanfaatan dana desa dapat disimpulkan bahwa, ide pembangunan Wisata Alam Denda Seruni dibangun setelah kepala desa Seruni Mumbul pulang studi banding pada Oktober 2018. Pada proses studi banding melalui habitus atau insting yang dimiliki oleh aktor kemudian menyarankan untuk mengembangkan wisata di desa, karena aktor ini berfikir bahwa dia juga memiliki potensi sumber daya alam yang sama, yaitu danau atau mumbul yang bisa dikembangkan menjadi objek wisata di Desa Seruni Mumbul. Proses perencanaan pembangunan desa yang 
dilakukan melalui musyawarah-musyawarah tersebut melahirkan suatu modal sosial dalam bentuk norma-norma, dimana dalam norma tersebut terdapat nilai-nilai agama yang dijadikan sebagai pedoman dalam pelaksanaan kegiatan pariwisata di Wisata Alam Denda Seruni. Melalui habitus yang dimiliki oleh agen Seruni Mumbul yang didukung oleh modal ekonomi melalui pemanfaatan dana desa, modal sosial, modal budaya dan modal simbolik menciptakan sebuah praktik sosial dalam pengembangan Wisata Alam Denda Seruni. Dalam pengembangan wisata Denda Seruni belum bisa memanfaatkan modal modal yang dimiliki secara optimal seperti, modal ekonomi berupa kepemilikan benda-benda seperti perahu potensi berupa lahan magrove yang bisa dijadikan objek wisata, tanah, rumah, serta kendaraan yang mereka miliki. Modal sosial berupa partisipasi dalam suatu jaringan, resiprositas, kepercayaan, nilai dan norma dan tindakan yang proaktif. Modal budaya yang dimiliki seperti nilai-nilai yang ada di masyarakat dan cerita legenda Denda Seruni belum dimanfaatkan dalam pengembangan wisata.Legenda Denda Seruni dapat menjadi peluang dalam menciptakan wisata edukasi bagi pengunjung. Selain itu modal simbolik berupa gelar, jabatan yang dimiliki oleh tokoh-tokoh masyarakat belum dimanfaatkan secara optimal dalam mensosialisasikan pengembangan wisata. Kurangnya sosialisasi yang disampaikan oleh Pemerintah Desa dan Pokdarwis kepada masyarakat terkait perubahan desa wisata menyebabkan kurangnya partisipasi dan rendahnya kesadaran masyarakat mengenai pentingnya pengembangan wisata di desa. Oleh karena itu pemanfaatan habitus dan modal-modal masyarakat Seruni Mumbul masih kurang maksimal dan belum efektif dalam pengembangan wisata Denda Seruni 
Pengembangan Wisata Alam Denda Seruni Melalui Pemanfaatan Dana Desa dalam Perspektif Sosiologis

\section{Daftar Pustaka}

Alwi, Hasan dan Dendy Sugono 2005. Kamus Besar Bahasa Indonesia Edisi Ketiga. Jakarta: Balai Pustaka.

Devy, Angga Hellen. 2017. Pengembangan Obyek dan Daya Tarik Wisata Alam Sebagai Daerah Tujuan Wisata di Kabupaten Karanganyar (Studi Kasus Obyek Wisata Air Terjun Jumong di Kawasan Wisata Desa Berjo, Kecamatan Ngargoyongso, Kabupaten Karanganyar). Jurnal Sosiologi DILEMA 32(1) 34-44. Diakses 8 Oktober 2019, dari http://jurnal.unc.ac.id/dilema

Ghony, M, Djunaidi dan Alamanshur, Fauzan. 2016. Metodologi PenelitianKualitatif. Jakarta Ar-Ruzz Media.

Hamzah, Suryani, Any dan Irfan, Mohammad. 2017. Buku Ajar Hukum dan Pariwisata. Kekalik Gerisak, Mataram NTB: Pustaka Bangsa.

Jenkis, Richard. 2013. Membaca Pikiran Pierre Boirdieu. Yogyakarta. Kreasi Wacana

Kessa Wahyudin. 2015. Buku 6 Perencanaan Pembangunan Desa. Kementrian Desa, Pembangunan Daerah Tertinggal, dan Transmigrasi Republik Indonesia Jl. Abdul Muis No.7: Jakarta Pusat 10110.

Krisdanto, Nanang. 2014. Pierre Bourdieu Sang Guru Damai. Jurnal KANAL 2(2) 107-206. Diakses 8 Oktober 2019, dari http://scholar.google.co.id

Pitana, I, Gede dan Gayatri, Putu G. 2005. Sosiologi Pariwisata.Yogyakarta: Andi

Profil Desa Seruni Mumbul 2019

Ritzer, George. 2006. Teori Sosiologi Modern. Jakarta: Kencana.

Setiyono, Tri, Agus. 2017. Strategi Pengembangan Obyek Wisata Taman Tebing Breksi Sebagai Daya Tarik Wisata di Desa Sembijero Kecamatan Prambanan Kabupaten Sleman Yogyakarta. Jurnal Student 6 (5). Diakses 8 Oktober 2019, dari http://journal.student.uny.ac.id

Sugiyono. 2017. Metode Penelitian Kuantitatif, Kualitatif dan R\&D. Bandung: Alfabet.

Suwantoro, Gamal. 2002. Dasar-dasar Pariwisata. Yogyakarta: Andi.

Yusuf, A. Muri. 2016. Metode Penelitian Kualitatif, Kuantitatif \& Penelitian Gabungan. Jakarta: Pranadamedia Group. 